\title{
Beyond "Progressive" Reform: Bodies, Discipline, and the Construction of the Professional Teacher in Interwar America
}

\section{Fonna Perrillo}

Rose Freistater was twenty-six years old when the New York City Board of Examiners denied her a teaching license. She had been teaching at James Monroe High School, first as a student teacher and then as a substitute teacher for five years, and her work was characterized by the chairman of the biology department in which she taught as "difficult to overstate in its excellence."' But in 1931, Rose stood five feet and two inches and weighed 182 pounds. When she applied for her teaching license that year, she weighed thirty pounds more than the maximum weight allowed by the Board for her height. She was given six months to lose thirty pounds; when she lost only twenty in that time, she was rejected by the Board altogether. Although a number of overweight and underweight teachers were rejected by the Board of Education in the ten years that the standards had existed, Rose was the first to appeal to the state that the qualifications were unfair. When her case reached the State Commissioner of Education in 1935, it was rejected again, and the city board issued a statement claiming, "Other things being normal, a person of abnormal weight is likely to have more absences because of ill health and be less efficient as a teacher than a person of average weight." Furthermore, it added, "Teachers must climb stairs, take part in fire drills, and be able to handle all real school emergencies. Overweight teachers are less likely to stand the strain of teaching. ... Teachers should [be] ... acceptable hygienic models for their pupils in the manner of weight." Finally, overweight teachers, who represented greater health risks than others, "constitute[d] a drain on the teachers' pension fund." In response,

Jonna Perrillo is a Ph.D. candidate at the Steinhardt School of Education, New York University. She would like to thank Jonathan Zimmerman for his constant engagement, enthusiasm, and support. She would also like to thank Robert Gunn, Carley Moore, and Nicole Wallack for their valuable criticisms and for their ongoing interest in this project. This essay won the History of Education Society's 2003 Henry Barnard Prize for the best essay by a graduate student.

25:6.

'“City Holds Woman Too Fat to Teach," New York Times, July 16, 1935: 21:8.

2 "Wants Teachers to Be Hygienic Models," New York Times, November 22, 1935:

3 "Big and Strong," Time, December 9, 1935: 64.

History of Education Quarterly $\quad$ Vol. $44 \quad$ No. $3 \quad$ Fall 2004 
the Freistater family contended that Rose walked the five flights of steps to their apartment several times a day, but her case was closed. ${ }^{4}$

Both Time and Newsweek reported the Freistater story for over six months; then, after her final rejection it disappeared. The beliefs about health, efficiency, and the professional responsibilities of the teacher that her case reflected, however, neither began nor ended there. Much has been written about educators' development of a disciplinary body of knowledge in the thirty years preceding World War I and, more specifically, about the benefits, limitations, and results of this disciplinary knowledge. ${ }^{5}$ Many of the watersheds of urban Progressive reform-including the introduction of intelligence testing, the implementation of a vocational curriculum, and the development of physical education and life-adjustment courses in the high schools-focused on reorganizing increasingly heterogeneous and expansive classrooms. Reformers bolstered academic changes by providing students with medical and dental care and hoped that improving student health would make classrooms more productive and efficient. The scientific and medical changes Progressive reform enacted were mirrored in educators' writing in the early twentieth century; the focus on surveys, case studies, and statistical analysis in education journals marked the literature as professional and classified teachers' knowledge as a discipline. With Progressive reform, teachers were no longer "natural" caretakers but professional ones equipped with the scientific methods and theories by which to best understand and serve children.

But if discipline was a path to advocacy in the Progressive era, it had by the interwar period taken a new meaning, shifting from a body of knowledge designed to remake the classroom to policies designed to makeover the women's bodies who occupied them. This essay will reveal experts' efforts to discipline the teacher in interwar America by attending to three important events that have been largely overlooked in the history of teacher professionalization: interwar experts' fascination with teacher types; their attempts to redress the unfashionable teacher; and the concern that a professional rhetoric of health expressed over teachers' individual and collective bodies. By the Progressive era, teaching had become a feminized profession, and that fact troubled some experts. Most notably, G. Stanley

4 "31 Pound Surplus a Weighty Matter in New York." Newsweek, July 27, 1935: 38-39.

5ee, for example, Raymond Callahan, Education and the Cult of Efficiency: $A$ Study of the Social Forces that Have Shaped the Administration of Public Schools (Chicago: University of Chicago Press, 1962); David Tyack, The One Best System: A History of American Urban Education (Cambridge: Harvard University Press, 1974); and Gerald Grant and Christine Murray, Teaching In America: The Slow Revolution (Cambridge: Harvard University Press, 1999). There is also a large collection of writing on the links between professionalism and the need for disciplines. See Thomas Haskell, ed., The Autbority of Experts: Studies in History and Theory (Bloomington: Indiana University Press, 1984) and Eliot Freidson, Professionalism: The Third Logic (Chicago: University of Chicago Press, 2001) for two strong examples. 
Hall worried that an abundance of women teachers could harm boys' development because they were "biologically and culturally" different. ${ }^{6}$ Concerns like Hall's were noticed but not mainstream; the profession was too dependent on women to question their right to be in the classroom. Even more important than the rising percentage of women teachers after Progressive reform was the increase in the number of working women, more generally, and in their collectivization. The rapid-growing consumerist culture of the 1920s opened new fields of employment to lower middleclass and middle-class women. For the first time, significant numbers of women worked for personal fulfillment in addition to economic necessity. As women became a more visible part of the workforce, a concern over their rejection of traditional gender roles in the 1920 s transformed into a Depressionprovoked fear that women were taking “men's" jobs. ' American working women seemed uncontrollable, unpredictable, and uninterested in their biological destiny as mothers.

Interwar experts, who responded to anxieties over women teachers, differed from their Progressive counterparts in several important ways: they were more clearly connected to a larger climate hostile to working women; they were more politically mainstream; and their concerns about women's bodies in the classroom focused on health and physical performance rather than a sense of biological difference. After World War I, the success of Progressive health reform met with a new cultural interest in personality and an expanding beauty industry; together, these phenomena directed experts' attention to monitoring and refiguring the teacher. These changes were formalized in legislation, in more frequent and comprehensive teacher evaluations, and more informally, in professional literature that fixated on the teacher's body. As a whole, such disciplinary measures served to reestablish the new "professional teacher" as subordinate to administrative control. Teaching had long been linked to a call to sacrifice in both material and social senses. But "the vows of poverty, celibacy, and obedience" that teachers complained they were required to take in the 1920s and 1930s- their dwindling and, at times, unreliable salaries, the laws that banned married women teachers, and the loyalty oaths that applied to all- reinforced the call in new and more explicit terms than before. ${ }^{8} \mathrm{An}$ increased focus on the personal and on what teachers did with their bodies outside of the classroom,

${ }^{6}$ David Tyack and Elizabeth Hansot, Learning Together: A History of Coeducation in American Public Schools (New York: Russell Sage Foundation, 1992), 157.

'Both Susan Ware and Alice Kessler Harris make this point. See Susan Ware, Holding Their Own: American Women in the 1930s (Boston: Twayne Publishers, 1982), 27 and Alice Kessler-Harris, Out to Work: A History of Wage-Earning Women in the United States (New York: Oxford University Press, 1982), 251.

${ }^{8}$ Agnes Doherty, "The Health of the Teacher," National Education Association fournal 62 (November 1924): 364-370, 365. 
in fact, became a way for experts to undermine their growing agency within it. By disciplining the teacher and thinking of her in relationship to an "ideal type" rather than as a person, experts worked to avoid the new convictions and concerns that teachers and other working women were registering as part of the larger culture.

Some of the consequences and contradictions of this disciplinary shift can be seen in the administrative action against Rose Freistater. Neither the quality of her teaching nor her mastery of an educational discipline were considered when the Board of Examiners denied her a teaching license. The Freistater case illustrates the degree to which the teacher's body had become a site of concern for educators in interwar America. The trope of the healthy teacher present in administrators' responses in her case allowed them to construct images of the professional teacher that distinguished her from teachers before Progressive reform. Importantly, teacher health was considered to be not just physical well-being but also psychological. The complete package by which a teacher was measured was what some called "personality and its accessories": good health, an attractive appearance, and, most importantly, a diligent sense of optimism and self-control. Implicit in the concern over teacher health, however, was a much larger concern about the health of the classrooms and of the schools. As in the two decades previous, education literature in the 1920s and 1930s was marked by studies that attempted to prescribe pedagogy through quantitative analysis. Survey after survey told teachers that "regimentation" in both their work and personal lives would have "a beneficial effect on their health." The regimentation of teachers' minds and bodies, educators argued, would filter down until, ultimately, the schools would be more orderly as well.

In fact, the increased professional standards that resulted from Progressive reform made teachers the subjects of scientific study. The development and widespread use of teaching evaluations after World War I meant that teachers were being watched more closely in the classroom, and a sense of surveillance existed in the form of guidelines for teachers outside of school, as well. Teachers were expected to perform as models of good health equally in their personal and professional lives. When they did not, the consequences could result in termination. Smoking and drinking bans were common for women teachers nationally. For example, Helen Clark, a teacher in Seacaucus, New Jersey, was refused her teaching certificate for smoking cigarettes after school hours. ${ }^{10}$ Such laws may have been written in gender-neutral terms, but they were used almost exclusively against women teachers, suggesting

${ }^{9}$ Herman Schulman, "Does Teaching Night School Shorten the Life of the Day School Teacher?" High Points in the Work of the High Schools of New York City [hereafter HP] 19 (March 1937): 20-23, 21.

10“"Smoking Teacher Loses," New York Times, January 26, 1927, 23:3. 
that the guidelines were less interested in the teacher's health than in some teachers' lifestyles. Concern over the ways in which women teachers, specifically, were conducting themselves outside school is all the more evident in the concurrent development of health and marriage bans. In 1931,70 of the nation's 93 largest cities released women teachers from their positions upon marriage, claiming that teaching required a woman's full energy and dedication. Even in New York City, which repealed its marriage ban in 1920, a female teacher who married while in service was required to report her marriage and the name of her husband to the superintendent of the schools." Such codes, a bureaucratic endeavor designed to survey women teachers, reflect the degree to which administrators conflated the disciplining of the teacher's body with the disciplining of the teacher herself.

Experts and administrators sought to produce a healthier and more effective teaching force. Studies published in education literature continually told teachers how to spend their leisure time, praising those who returned to school after the summer vacation with "pliant muscles and good resistance."12 In addition to engaging themselves in social and cultural activities to improve their intellect, teachers were encouraged to eat healthfully, get adequate sleep, and engage in regular exercise. Such teachers, wrote education professor Henry S. Curtis, "will be, on that account, a more wholesome model to set before children. .. more popular and more copied.... Her health and vitality will be a large element in her success in teaching arithmetic, geography and every other subject; for without health she cannot have enthusiasm or buoyancy or attractive ways. ${ }^{13}$ Vitality, as Curtis' writing reflects, became a key term in the years following World War I, and it signified both physical wellness and a lively, pleasant demeanor. The new teacher, a product of Progressive reform, was not just knowledgeable but attractive, persuasive, and energetic. In classrooms that were overcrowded despite the segregation of students within a differentiated curriculum, influence was a critical skill; teachers were not just disciplinarians but role models who should inspire students to learn and maintain order in the classroom through personal persuasion. Administrators reminded teachers that "We all know that pupils will imitate the good and bad habits of teachers; that the nervous teacher is apt to make his class nervous; that the calm, restful teacher will generally have a quiet and orderly class. ${ }^{14}$ Linking teacher health to student performance enabled educators to claim that both could be measured and quantified and,

\footnotetext{
"Howard K. Beale, Are American Teachers Free? An Analysis of Restraints Upon the Freedom of Teaching in American Scbools (New York: Scribner's Sons, 1936), 384; The Teacher's Handbook (New York: Board of Education, 1928, 3rd ed), 46.

"Blanche Howell, "Creative Resting," HP 14 (Sept. 1932): 42-43, 43.

${ }^{13}$ Henry S. Curtis Recreation for Teachers (New York: Macmillan Company, 1918), 13.

${ }^{14}$ Hector LaGuardia, "The Teacher's Role in the Development of Student Personality," HP 20 (January 1938): 42-47, 48.
} 
therefore, both could be demanded in school board laws and in the increasing number of teacher evaluations.

Precisely how often teachers were physically ill is difficult to know, but in 1922 The New York Times reported that one of out every ten teachers was reported absent from school each day. ${ }^{15}$ Widely read studies, such as William E. Chancellor's The Health of the Teacher, claimed that "the occupation has very high rates of both death and disease." ${ }^{16}$ More specifically, psychologist Lewis Terman explained, "The teacher's excessive liability to tuberculosis should hardly occasion surprise. ... For six to eight hours a day the teacher breathes ... the mineral dust of chalk and soil, lint from clothing of forty or fifty children, millions of cast-off cuticles from their bodies, and foul bits of epithelial tissue from respiratory passages." ${ }^{17}$ Certainly overpopulated classrooms with potentially ill students provided conditions for disease, but rhetoric such as Terman's heightened a larger sense of schools as contagion zones in which healthy children and adults could become ill if not for their hygienic reorganization. Terman and many of his colleagues would measure immunity in biological and psychological terms, prizing the ability to fight off tuberculosis as well as to maintain one's "mental economy." In both cases, preservation of the teacher's natural vitality was critical. The qualities of a dangerous teacher- "irritability, nervous distraction, dogmatism, [a] strident voice, superficial demonstrativeness, [and] indulgent solitude"were believed to be "but a composite photograph of ill health and fatigue." Inefficient teachers who wasted their natural resources threatened to mishandle and poorly influence their students. If fatigue was not contagious, then, the symptoms it manifested created their own series of problems in the classroom..$^{19}$

By the time the Freistater case went before the state commission in 1935, teacher health had become a significant factor in an effort to bring order to struggling urban schools. A rhetoric of teacher health was enveloped within a rhetoric of school reform and, more specifically, a desire to create a healthier school body. Similarly, the refusal of the New York City Board of Education to grant Rose Freistater a teaching license was just one manifestation of a broader struggle over the changing expectations of teachers in the face of schools that were more expansive and, at the same time, more fragmented than ever before. Freistater's body symbolized a rejection of

15“"One Teacher in 10 is Declared Absent," New York Times, May 13, 1922: 18:1.

${ }^{16}$ W.E. Chancellor, The Health of the Teacher (Chicago: Forbes and Company, 1919),vii.

${ }^{17}$ Lewis Terman, The Teacher's Healtb: A Study in the Hygiene of an Occupation (Boston: Houghton Mifflin, 1913), 26.

${ }^{18}$ Ibid., 62.

"The newly differentiated curriculum -one designed to make classes more homogeneous and, therefore, to feel more managable-was meant to prevent teacher fatigue in addition to protect high-performing students from their "unfit classmates." 
the ideal image of the teacher, even, her chairman suggests, as she performed ideally in the classroom. In the interwar period, the anxieties over a female profession became expressed through anxieties over the female body, especially bodies that were seen as unproductive, inefficient, or self-indulgent. The "acceptable, hygienic model" that administrators and educational experts developed for teachers went far beyond actual, physical health but became a coordinated effort to shape teachers' lives and bodies into an ideal American type: healthy, optimistic, and self-controlled. The standards that prohibited Freistater from becoming a teacher were part of a larger set of guidelines, both formal and informal, that worked to shape teacher behavior and to transform the image of the teacher from a domineering schoolmarm to a compliant and capable professional. The subject of these guidelines extended from pedagogy to attitude to physical appearance, but they all worked toward the same goal. In a period marked by extremes-war, a rapidly developing consumer and technological society, and financial collapse-teachers were made into figures of moderation, in their personalities, in their beliefs, and even in their bodies.

\section{Combatting Schoolmarmitis}

In 1935, an anonymous writer, calling him or herself R.I.P., wrote an article in High Points-a journal written by and for New York City high school teachers-entitled, "On Becoming a Teacher." In it, R.I.P., writing under the guise of a new female teacher, portends the future: "I'll hate [teaching] for a few years, and then I'll grow ambitious to be the acting head of the department, and then I'll learn to love my work .... I'll start making speeches at the beginning of the term about the Student's Debt to the City of New York, How to Use Textbooks as a Careful Citizen Should, The Importance of Two Inch Margins (on both edges of the paper), and so forth. I'll discover a soul-mate in the French teacher who adores Joan of Arc, and we'll spend our lunch hours together, calling each other 'girls." As if to seal her fate, R.I.P. writes, "I'll get much, much fatter." ${ }^{20}$ In contrast to the Freistater case, R.I.P. reads overweight as clearly signifying something larger than appearance or health; rather, fat is symbolic of the problems with the developing profession. Her vision of a teacher, though satirical, delineates what the schoolmarm had become by the 1930s. Always a figure of severity and lack of humor and always a spinster, the schoolmarm of the interwar

${ }^{20}$ R.I.P., “On Becoming a Teacher," HP 18 (May 1936): 51-52. What makes me wonder if R.I.P. is a man is the characterization of the protagonist and her friend "calling each other girls." Jackie Blount has exposed the fear of same-sex relationships among women teachers, both sexual and not, in this period. See Jackie Blount, "Manly Men and Womanly Women: Deviance, Gender Role Polarization, and the Shift in Women's School Employment, 19001976," Harvard Educational Review 66 (Summer 1996): 318-338. 
years had been modernized to represent 1920s and 1930s anxieties and concerns: not just stern but obsessive, not just unmarried but dependent on relationships with other teachers, and not just dowdy but fat. In short, the stereotypical teacher was the image of a failed woman in every sense: unattractive, unsocialized, and unproductive. Not yet a schoolmarm, R.I.P. eulogizes the inevitable death of herself as a woman. To embody the image of the teacher, she suggests, was more than an occupational hazard but a byproduct of taking the work seriously. In employing images that would resonate with large-scale beliefs about failed women, she laments in her own loss the losses women teachers incurred as a whole.

More specifically, the schoolmarm image was a product of the tension between the feminization of the profession and the drive towards professionalism. "Teaching is a man-sized job," one expert noted, but by 1920, 80 percent of the urban teaching force was female. ${ }^{21}$ Teachers, many of whom were unmarried and all of whom worked outside the home, defied traditional notions of women's roles even as they performed an important social and feminized function. By the interwar period professionalism required teachers to stay on the job longer than they had before. Administrators and experts feared teachers would see that nearly twice as many married women worked than twenty years earlier and would demand the same rights as other women. ${ }^{22}$ Equally important, the openly xenophobic and hereditarian arguments that had dominated much of urban Progressive education politics in the first quarter of the century were quickly shifting to a "positive eugenics" and a concern over the reproductive responsibilities of white, middle-class women. ${ }^{23}$ Women who remained unmarried or childless were not just unwomanly but un-American. Teachers, who were largely native born and white, if not comfortably middle class, posed a difficult case to positive eugenics. In balancing between performing as natural caregivers and as carefully trained professionals, women teachers needed to bring to their work dedication and thought, but not too much of either. Some teachers who "[were] prone to take themselves and their work too seriously" risked forgetting their other important responsibility: to be good women. ${ }^{24}$

${ }^{21}$ Phi Delta Kappa, Teaching as a Man's fob (Homewood, IL: Phi Delta Kappa, 1938), 8. Statistic found in Kate Rousmaniere, City Teachers: Teaching and School Reform in Historical Perspective (New York: Teachers College Press, 1997), 35.

${ }^{22}$ Susan Ware shows the percentage of working women continued to increase during the Depression. In 1900, 5.6\% of American women worked; in 1930 the number had nearly doubled to $11.7 \%$; by 1940, 15.2\% of American women worked. See Ware, Holding Their Own, 29.

${ }^{23}$ For more on the unmarried working woman, see Susan Ware. For more on the turn of eugenics in the 1930s, see Wendy Kline, Building a Better Race: Gender, Sexuality, and Eugenics from the Turn of the Century to the Baby Boom (Berkeley: University of California Press, 2001).

${ }^{24}$ William Felter, "Easy Markers, Hard Markers," HP 4 (September 1923): 3-4, 3. 
The fear of women who "act[ed] as if they were men" drove experts to respond. ${ }^{25}$ In the interwar period, they began to focus on teacher types, much as they had focused on student types a decade earlier. Typing, as part of the eugenicist framework that Terman and others introduced into the high schools with intelligence testing and student case studies, had most frequently focused on "bad girls" and their mothers. Now typing turned to problematic women on the other side of the desk: teachers. Teachers such as R.I.P. argued that "schoolmarmitis" was a phenomenon that happened to otherwise good women, but typing suggested that schoolmarms came to the profession already flawed. A popular work by sociologist Frances Donovan, The Schoolma'm, outlined the following "queer teacher" types: the voluble, the penny-pincher, the sentimental, the pest, the moody teacher, the aloof teacher, the bootlicker, the fanatic, the cynic, and the persecuted. Each type shared, in addition to asocial and excessive behavior, a mode of performance that "tends to force her point of view on [the student], to compel him to memorize rather than develop the power to evaluate, and makes him so aware of her queerness that he had neither time nor energy left to realize his own needs." "Q6 "Queer," dominating teachers literally drew the energy out of the room, leaving students lifeless. Such women were the inversion of caretakers, but Donovan's stereotypes of problematic teachers were rooted in female stereotypes all the same. All were excessively sensitive or neurotic, and all lacked self-discipline. In short, all were portraits of the character types that American women were not to be.

Much as typing students allowed educators to transfer poor performing students out of academic classrooms, typing teachers divested experts and administrators from the responsibility of ruining good women. By arguing that the profession attracted women who craved authority, they did not have to confront the ways in which school policies were failing teachers. Despite the adoption of intelligence testing and a differentiated curriculum, classrooms still lacked resources and served more students than ever. But the fear of schoolmarmitis on the part of experts, administrators, and teachers alike often reflected complicated, ambiguous feelings toward working women and toward the massive institutions urban schools had become. With the Progressive interest in typing came a belief that the ways in which teachers had been expected to perform in the past-to maintain order, to discipline, and to focus on the intellectual content of their work-were insufficient for molding

${ }^{25}$ Olga Knopf, The Art of Being a Woman (Boston: Little, Brown, and Company, 1932), 252. Another sign of this anxiety over the feminization of the profession can be found in literature from the period that worked to recruit male teachers. Studies such as Teaching as a Man's Fob (1938) and The Young Man and Teaching emphasized strength as a desirable characteristic and encouraged men to remember that "the exercise of power is pleasing to many." See Henry Parks Wight, The Young Man and Teaching (New York: Macmillan Company, 1920), 6.

${ }^{26}$ Frances Donovan, The Schoolma'am (New York: Frederick A. Stokes, 1938), 97. 
successful students. These skills neither inspired students nor built character within them. The image of the interwar schoolmarm was of a woman who had not kept pace with the changing times and focused too heavily on the pre-Progressive requirements of teaching. At the same time, that image exposed the way in which order and discipline in the classroom were more important than ever. "School plants" - schools overcrowded with an increasingly heterogeneous population - only required teachers to have more authority and stronger organizational skills in the classroom than before.

This fear of teacher authority was reflected in the shift in the image of the schoolmarm from anemic in the nineteenth century to overweight after Progressive reform, for if the former reflected a subordination of bodily desires, the latter was an act of surrender. Educators believed that because the schoolmarm lacked control over her own body she, therefore, worked to control others, both in her interpersonal reactions and in pedagogical techniques that left students with no room for personal expression or exploration. Administrators frequently blamed this penchant for control on a teacher's fragile mind. Henry Rivlin's claim that "it is small wonder that the conscientious teacher is exhausted by her day's work. When the teacher is high-strung to begin with, the emotional strain of teaching is harmful to her and to her class" reflects the period's concern with the unstable and uncontrolled teacher. ${ }^{27}$ Such women were figures of excess, overspent, but overspent because they exerted too much nervous energy to begin with. It is the teacher with "undisciplined organization, the teacher with intelligence highly developed and emotions uncontrolled, the teacher with restricted personality, that wastes lives of hundreds of children in the schools and lowers the efficiency of the noblest of institutions, the public schools" claimed Angelo Patri, a New York City administrator. ${ }^{28}$ As class sizes increased and each teacher became responsible for hundreds of students, her influence and potential for harm increased in importance.

Much like the move toward a more scientific methodology in the previous decades, the mantra of self-control that entered education literature in the 1920s, and echoed throughout the 1930s, mirrored a larger cultural phenomenon of the time. Self-control referred both to the character trait and to the larger act of fashioning the self. Both notions were aided, if not created, by one of the most significant social developments of the interwar period: the development of a large-scale advertising culture. In establishing ideal types for Americans, advertisements sold the idea that consumers' destinies were in their hands and in the products they purchased. People were no longer believed to be mere compilations of the ethical and moral

${ }^{27}$ Harry Rivlin, Education for Adjustment: The Classroom Applications of Mental Hygiene (New York: D. Appleton and Company, 1936), 401.

${ }^{2 x}$ Angelo Patri, “A Plan for Apprentice Teachers," HP 10 (March 1928): 18-20, 18. 
beliefs that they adopted through environment or experience but instead enactors of their own personalities: carefully cultivated presentations of the self. $^{29}$ Teacher education and education literature responded to this focus on constructed selfhood by prioiritizing performance as a way of understanding the practice of teaching as it had not been before. As educators became more aware of a symbiotic relationship between teachers and students, they also became increasingly concerned about teacher types and the influence that such types could have upon youth. At least some administrators and experts saw that the scientific efforts of Progressive reform were not enough to transform the problems of the classroom. Every teacher still had poor performing and behaving students, even if many of the most delinquent students were systematically sent to a vocational or industrial curriculum. If rationalist reform had not entirely succeeded at an organizational level, then, it might not be enough to work on the individual level, either.

Curing schoolmarmitis required a radical retyping of the teacher's personality. Redefining the teacher type became the objective of experts and administrators in the interwar period. If the "type" could be changed from schoolmarm to professional, they argued, teachers could direct themselves towards the new objective. Personality became a new element in the definition of the profession and of classroom pedagogy, for in the words of one New York City principal, “. . . the scientific method alone does not suffice as a character-building force. It is cold and impersonal. Much of human conduct is warm and impulsive. ${ }^{30}$ Experts and administrators believed ideal teachers could model ideal behavior for students who were living in a changing culture. If the ideal character traits from the Progressive era were loyalty, efficiency, and industry, the ideal personality traits of the teacher after World War I were somewhat different. To be sure, responsibility, social-mindedness, efficiency, loyalty, industry, and physical and mental health were now considered optimal personality rather than character traits, even if they meant much the same thing. Always, good health was equated with being a good person. Now, however, administrators and experts added tact, cooperation, kindliness, cheerfulness, adaptability, and self-control to the qualities most sought in teachers and most important to teach to students. ${ }^{31}$

For teachers, acts of mind were measured more than ever through bodily acts. Administrators evaluating teachers in the classroom looked for professional appearance, poise, alertness, and neatness as signs of good

\footnotetext{
${ }^{29}$ For a much more detailed account of this process, see Jackson Lears and Richard Fox, The Culture of Consumption (New York: Pantheon Books, 1983) and Warren Susman, Culture as History: The Transformation of American Society in the Twentieth Century (New York: Pantheon Books, 1984).

30"What Relationship Should Exist Between Teacher and Pupil?" HP 18 (May 1936): $7-9,9$.

"Bella M. Bator Chase, "Character Training in the Public Schools." HP 20 (February 1938): 18-22, 22.
} 
teaching. Shrill or strident voices, experts warned, brought injury to the throat but were also a sign of "lack of breeding." In order to affect the enthusiastic but self-controlled professional, teachers were urged to remember that "the use of the voice must be correlated with facial expressions and general mannerisms." New York City teachers' manuals advised readers on vocal control, personal appearance, how to carry themselves in the classroom, and how to arrange their desk drawers-all actions principals would assess as part of merit exams that qualified teachers for promotions. ${ }^{32}$ Such evaluations were not only similar to the kinds of observations teachers were being asked to make about their students, but in fact stemmed from the same source. Psychologists such as Lewis Terman and Edward Thorndike claimed that personality could be measured objectively through a person's physical performance. Doing so allowed administrators to attend to both scientific and rational methods without losing attention to the emotionalism and sympathy that all claimed were so integral to teaching. ${ }^{33}$

Above all other qualities, however, administrators and experts stressed the importance of optimism and asked of teachers, "What business is there in the world that depends so much on the brighter side of emotions as teaching does? What is there that strengthens teachers more than cheerfulness, happiness, and encouragement does?" ${ }^{34}$ If the classroom still contained many ills, optimism was often construed as the antidote, capable of inspiring students to do their best work and to learn to love the subject matter. With just the right attitude, any student could be a good student or, at least, the best student that his or her natural capacities allowed for; teachers were to model this attitude with their own cheerful and indefatigable performance in the classroom. To do so also modeled for students a sense of constant enthusiasm, even toward work that was undesirable. "We should remember," warned one administrator, "that one test of a well-adjusted personality, is the willingness to do tasks that are necessary but disagreeable, and to do them, if not joyfully, at least without making too great a fuss about it." ${ }^{35}$ In subordinating their competing desires to an optimistic frame of mind, teachers were to stay true to the new type.

Teachers recognized the conflict in these expectations. They recognized the conflict not only in the rhetoric of administrators and experts but also

\footnotetext{
${ }^{32}$ The Teacher's Handbook (1928); Benjamin Rosenthal, "Pupil-Teacher Relationship" HP 16 (January 1934): 50-54, 52.

${ }^{33}$ These kinds of merit exams mirrored what was occurring in the civil service and, to a more limited degree, private industry, at the same time. Merit exams, it has been argued, worked to regulate gender and racial diversity in fields that were less feminized than teaching. For an example of this argument and more on meritocracy exams in the 1930s and 40s see Margaret Rung, Servants of the State: Managing Diversity and Democracy in the Federal Workforce, 1933-1953 (Athens: University of Georgia Press, 2002).

${ }^{34}$ William McAndrew, "The Baconian Theory of Life," HP 1 (May 1919): 3.

${ }^{33}$ LaGuardia, "The Teacher's Role in the Development of Student Personality," 48.
} 
in guidelines for classroom performance, asking, "Our text-writers urge the necessity of personality in the teacher. But what if the pedagogical procedures drive the little personality we have out of us, and leave us colorless and dry?" ${ }^{36}$ Aware that their optimism was often being evaluated, teachers complained that "in the ordinary recitation section there is little opportunity to show ourselves particularly 'poised,' 'tactful,' 'decisive,' or 'resourceful."' ${ }^{7}$ Despite the development of more progressive education theories, teachers were often encouraged to practice familiar methods in the classroom that were uninventive, at best. To be more efficient, they were encouraged to substitute less substantive, easier-to-grade quizzes for exams and to outline lectures on the chalkboard rather than engage in undirected conversation. ${ }^{38}$ Teachers who wanted to be more inventive, as many did, were often limited by the architecture and resources of their classrooms. "I can envision students clamoring for a period in grammar-a thing most of us now only see in our deluded dreams," wrote one such ambitious teacher, "Sometimes those dreams are wrecked by nightmares. I think I am in a prison where everything is nailed down to the floor. How can you teach 'creative thought' or 'creative composition' to 35 or 40 souls that are chained to the ground?" ${ }^{39}$ Much professional literature of the period advocated rigid attention to technical details and the subordination of imagination to order. That advocacy conflicted with experts' call for the development of interesting and engaging teachers. In fact, much of the experts' advice sounded perfectly schoolmarmish: uncompromising and inflexible.

One difficulty that educators of the period could never resolve, or even respond to directly, was the possibility that teaching itself made women into schoolmarms. That would have required experts and administrators to consider seriously and address the increasing demands of the profession. Admininistrators wanted a cheerful, altruistic teacher, but often found themselves confronting a workforce that felt overstrained, underpaid, and mistrusted. R.I.P. suggested that the social problems educators feared come from teachers who are not really allowed to be women: "I shall be an old maid. Mark my words. I shall be a crabbed spinster. I'll get into a school where the only men are the janitor, the principal-aged sixty-two, and twice widowed-and the head of the Science Department, who was horribly mutilated during the Spanish American War." ${ }^{40}$ Even in New York City,

${ }^{36}$ Abraham Gedulig, "Should We Indoctrinate?" HP15 (October 1933): 26-32, 32.

${ }^{37}$ Mabel A. Bessy, "Supervision and the Improvement of Teaching," HP 6 (November 1924): 27-30, 28. 1933): 173-

38“Saving Energy for the Classroom, A Plea for Better Teaching," Education 54 (November

$177,176$.

${ }^{39}$ Sarah Thorwald Steiglitz, "My Class Struggle," HP 20 (March 1938): 46-52, 48.

${ }^{+0}$ R.I.P., "On Becoming a Teacher," 51. 
where marriage laws no longer restricted teachers to the single life, the social environment of the profession did, encouraging teachers to become permanent caretakers of other people's children. How to hold onto an experienced staff without their falling prey to schoolmarmitis was a question experts worked to negotiate during the period. Over time, experts and administrators focused on the teacher's body as an indicator of the problems of their urban schools; the effort to transform the teacher, then, ran parallel to the larger problems they could not change within the schools.

\section{Refashioning the Teacher}

"Every teacher has the right to be good-looking" wrote Harry Curtis, author of the widely read Recreation for Teachers, in 1918: "there is no place in life where a handsome woman cannot obtain more than a homely woman can, whether it be as an actress, a stenographer, or a saleswoman." ${ }^{+1}$ In coordinating a call for glamour with the language of natural rights, Curtis echoed larger beliefs about beauty that would come to dominate the following two decades. The development of a beauty culture, harnessed by the popularity of film and advertising images, as well as the growth of the cosmetics and ready-to-wear industries, told women that beauty was within the reach of all, and, in fact, it was a woman's responsibility to be beautiful. To be beautiful, or at the least, fashionable, had long been associated with a sense of moral righteousness; the patriotic fervor following World War I, along with increased popular attention to body images, made the attainment of beauty simply American. Glamorous women represented all that interwar American culture believed itself to value: the freedom to create oneself, the resources to express that self-creation, and an underlying identification with mass culture that gave boundaries to both. For working women, the responsibility to be beautiful was not just to her husband but also to her boss and, as Curtis and the culture at large suggested, the fulfillment of this responsibility would be awarded appropriately. Glamour became a means of negotiating the new women professionals within a culture that remained hostile to working women. Teachers, less glamorized in advertisements and popular images than secretaries and saleswomen, found themselves nonetheless at the center of a discourse that conflated beauty with personal agency and the health of one's personality with a healthy glow.

With the assistance of a larger culture increasingly interested in beauty as a performative act, education experts saw that one way to change the image of the schoolmarm was to change the teacher herself. To do so would narrow the gap between the new personality type and the typical appearance of the teacher. Since the turn of the century, beauty standards had consciously

${ }^{+1}$ Curtis, Recreation for Teachers, 7-8. 
moved away from the image of the stout, maternal, and asexual Victorian woman. Advertising images show that the ideal female figure became increasingly thin from 1900 to 1920 as hemlines shortened and corsets were traded in for less restricting undergarments. Women saw the values and beliefs of the Progressive era reflected in these fashion changes, not just in greater independence for women but also in a penchant for health and hygiene. Wrote one such teacher: "Some years ago, say around 1900, the style of dress worn by most women was neither comfortable nor attractive (we thought it was). There was the shirt waist with the collar so high and so tight one's ears were in constant peril, the skirt with the train which was propelled around the schoolroom carrying a million microbes furnished, in part, by every family in the district." ${ }^{" 2}$ The very professionalization of teachers and the efforts of school reform could be read through the changes in their clothing. These physical changes also enveloped a collection of beliefs about the personality and social status of the modern woman. Flappers, even with short hair and thinner, more boyish figures, were seen as more feminine and more sexual than their own mothers had been precisely because of the drastic break they had made with the conventions of the previous era. With the demise of the flapper image in the 1930s and the return of longer skirts and a more conservative glamour, advertisements and film continued to depict the working woman as sexy, single, and more independent than previous generations of women. ${ }^{43}$

Nevertheless, teachers, in popular imagery, had fallen behind other working women. Consistently, teachers of the 1920 s were seen to be more Victorian than flapper, more schoolmarm than stylish. Some of this imaging came from the fact that teachers worked with children and a resulting cultural desire to see them as maternal rather than coquettish. When Frances Donovan wrote in 1938, "Though she may be thirty pounds overweight, popular conception sees her in a hard thinness of personality ... Though her hair is bobbed and curled by the best artist of permanent waving, it retains its uncompromising stiffness. She may buy her frocks in the most exclusive shops, but they cannot conceal her occupational identity," she describes how entrenched the Victorian image of the teacher was. ${ }^{44}$ Stiff, determined, and asexual, the teacher was everything that film and advertising images encouraged women to reject. But critiques of the teacher were not limited to popular images outside the profession. Teachers had a real image problem, many educators noted, and a good part of the problem was their own fault. "Have you ever stepped back at association meetings or teacher

\footnotetext{
${ }^{42}$ Gertrude Hyde, "Then and Now," New York State Education 15 (April 1928): 558.

${ }^{43}$ For more on working women and beauty culture see Lois Banner, American Beauty (Chicago: University of Chicago Press, 1984).

${ }^{+}$Donovan, The Schoolma'am, 14.
} 
assemblies and in cold blood, scientifically and honestly studied the costumes of the attending teachers?" asked Katherine Kumler. ${ }^{45}$ Teachers, Kumler suggests, were not even trying.

What was the cause of such fashion faux pas? When one teacher claimed to Newsweek magazine "Teaching brings its own glamour. Teachers do not require an artificial variety," she may or may not have represented the majority of teachers' beliefs, but she most certainly reinforced cultural stereotypes of the teacher as deluded in her own importance. ${ }^{46}$ Such delusions only prevented teachers from giving attention to their looks. Some sympathetic experts and administrators were willing to believe that teachers' fashion problems were linked to the larger social restrictions they faced. "The teacher is surrounded by taboos," Harry Rivlin contended. "The young woman must dress in the conservative styles that the mothers of her pupils would never wear. In a community that accepts reasonable use of cosmetics and tobacco, the teacher is nevertheless supposed to set an example of abstinence. ${ }^{"{ }^{77}}$ Far more often, experts explained teachers' lack of fashion and beauty sense on their state of mind. "Teachers are intellectual rather than physical," one state supervisor explained, "they place a lower premium on the acquisition of clothes and, hence, many are careless of their appearance .... Often there is a lack of competition. Since other teachers in the building care little for dress, not much incentive exists to spur one on to improvements in personal appearance." ${ }^{\prime 48}$ Only women "on the fringes of society," especially immigrant and AfricanAmerican women, created as much concern as teachers in regard to their ability to see and participate in mainstream fashions. For all, fashion experts linked a call for better dress to a belief that glamorous women were "more efficient thinkers" and better citizens. ${ }^{49}$ Fashionable women, like public schools themselves, were understood as part of a larger conversation about American values and an ideal society.

For this reason, it was all the more important that teachers were, in fact, fashionable; some experts read glamour as a responsibility to those whom the teacher served. "Good taste in dress should be an important requirement for a teacher," argued one such expert. "When one is well dressed, one has more confidence to appear before and meet with other people." ${ }^{5_{0}}$ Better dress, experts came to believe, would lead to a better sense

\footnotetext{
${ }^{45}$ Katherine Kumler, "How Shall the Teacher Dress? On What Price 'Smartness'," New York State Education 15 (April 1928): 549-550, 549.

46"Schoolroom Glamour," Newsweek (July 24, 1939): 36.

${ }^{47}$ Rivlin, Education for Adjustment, 406.

${ }^{48}$ Lillian Gray, "Suitable Dress for Professional Women," Fournal of the National Education Association 21 (January 1932): 3-4.

${ }^{40}$ Jenna Wiessman Joselit, A Perfect Fit: Clothes, Character, and the Promise of America (New York: Metropolitan Books, 200), 39. 1928): 551 .

${ }^{50}$ Hazel Thorp Hathaway, "Costumes and Figgers," New York State Education 15 (April
} 
of one's own professional value. The resulting response was a call to action that encouraged teachers to express their talents through their physical appearance while reminding them that it was their responsibility as women to do so. Articles that appeared in the Fournal of the National Education Association and New York State Education could sound more like Ladies Home fournal than the typical professional publication, as they reminded their readers, "If teachers are really intelligent, they will make an effort to look their best ... the teacher can always study Vogue, Harper's Bazaar, and other excellent authorities on style. She can also study her reflection in the mirror and decide to do something about it." ${ }^{51}$ In a move that joined women teachers and their university-level counterparts in a shared project, professional attire became a subspecialty for female education experts and supervisors.

As with the larger movement that transformed housework into a domestic science, an attention to fashion and beauty coordinated with the scientific rationalism that had defined Progressive politics and reform. In encouraging women to follow "smart" rather than "pretty" woman fashions, experts encouraged teachers to construct wardrobes that valued comfort as much as style and required both. Teachers were not like the women they might see in fashion magazines, they were reminded, but they had become a sector of the fashion industry, part of "a great number of women who are able to earn outside the home" who demanded "garments that will stand the strain of wear and contribute to the health and efficiency of the wearer." ${ }^{52}$ The "smart look" meant wearing clothes that were neither too revealing nor too heavy, hats that were stylish but not too large, and shoes that were "efficiently fit" and not too narrowly cut. The smart look was also defined by more specific stylistic choices, and smart women dressers were encouraged to look at themselves in the mirror "with an outsider's eye." "If your costume looks really smart," recommended fashion experts, "you will see ... a unity of color, or else it will have one dramatic color note. Above all it will give the impression of one central idea that is instantly apparent." From such professional attire experts read the coordinated, well-organized, and efficient teacher. Women with less money to purchase clothes could make the most of a few well-chosen pieces that matched almost everything. "Harmony of color," rather than contrast, expressed through matching gloves, dress, purse, shoes, and hose gave smart women "an effect [of] a whole, something she has chosen to build up cleverly." ${ }^{\prime 3}$ Rather than originality, fashion experts emphasized a sense of design, forethought, and self-control-all skills that women were to enact in their teaching, as well. Any woman who might

\footnotetext{
"Gray, "Suitable Dress for Professional Women," 4.

${ }^{52}$ Louise M. Walter, "The Relation of Dress to Personality," HP 15 (October 1933): $43-5,44$.

"Gray, "Suitable Dress for Professional Women," 3.
} 


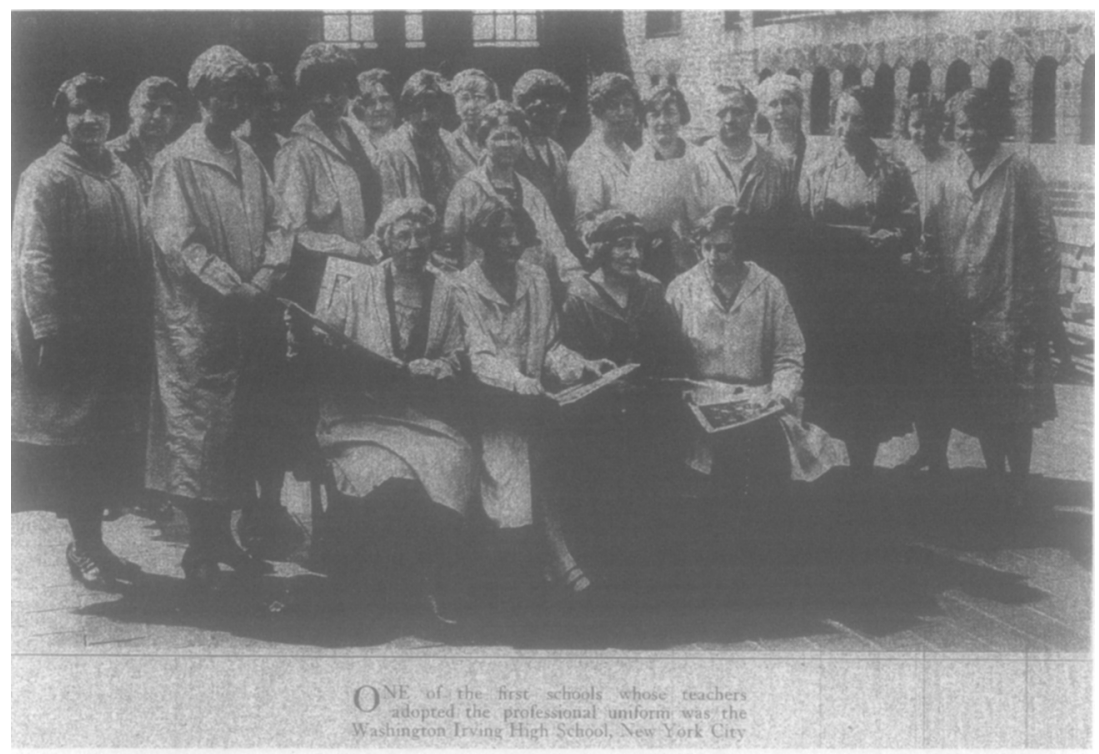

Figure 1. This 1926 photograph of Washington Irving High School teachers shows the faculty experimenting with uniforms in the form of lavender laboratory coats. Washington Irving led the student intelligence test movement in New York City during the Progressive era. In both their methodology and their appearance, these women fashioned themselves as scientists of education. Educational Review 71 (May 1926): 2.

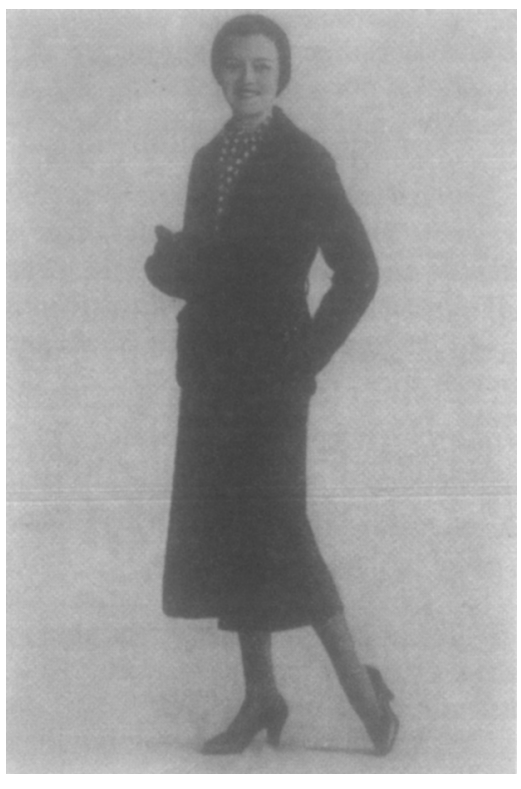

Figure 2. By the 1930s, the conformity of teachers' uniforms would be seen as unfashionable and, as a result, unprofessional. Lillian Gray, education expert, is seen here in an outfit of her own creation, one that created "a picture, an effect, a whole." In the Fournal of the National Education Association, she reminded her reader that "the smarter the teacher, the more smartly she'll dress." Lillian Gray, "Suitable Dress for Professional Women," Fournal of the National Education Association 21 (January 1932): 3-4. 
complain that her creativity was stifled by the "smart look" was reminded that fashion for the teacher was not just an expression of the body but also an act of mind. "Making the most of our assets is not brought about by accident but by serious thought," argued one expert, "If we do not know our assets and liabilities, look in the mirror, ask questions, and analyze our most becoming garments and determine what it is about them that gives us pleasure. It is sanity not vanity!" "It was only rational, experts contended, that women would want to look their best.

Underlying a professional discourse of fashion was the recognition that teachers, like many single, working women, were straddling class brackets. They were not as comfortably middle class as administrators and experts might have liked them to be, and this caused problems even as school boards consistently froze or cut teachers' salaries in the 1930s. Arguably, much of Progressive school reform had been based on the transference of middle-class values in the classroom. Teachers were to dress the part and present themselves as both feminine and middle-class icons. If teachers had less financial means to be beautiful than other women, they were encouraged to remember that the newly mass-produced beauty industry was available to all at one price or another. "In the absence of a lady's maid, you will need to be your own for your wardrobe and your body must be kept fit," wrote Katherine Kumler. "Ready-made clothing, cleaning establishments, beauty parlors, turkish baths, out-door sports and indoor luxury are all at your command." If teachers did not have all the luxuries, as the most glamorous of women, they still had sufficient means to do their best. Again, experts called on teachers' sense of public duty and reminded them that "To support American's reputation for carefully dressed women, the school teacher must be on the 'qui vive."'s5

In the twentieth-century belief that glamour was, while culturally mandated, also an expression of self, experts saw an opportunity to return to the teacher-type and make more of the relationship between personal and professional self. Beauty became an unofficial curriculum in educating the teacher. Percival Simmons, a professor at Teachers College, encouraged his students to "Go out and have a good time ... [wear] a touch of lipstick, shorter skirts, a new hat .... [B]y turning on the glamour... [you let] your personality sparkle." ${ }^{16}$ On one hand, Simmons encouraged his students to think of themselves as mainstream culture encouraged all women to think of themselves: as potentially glamorous and interesting. At the same time, experts compelled teachers to consider themselves members of a special

${ }^{54}$ Beulah Blackmore, "The Clothes We Wear," New York State Education 15 (April 1928): 552-558, 553.

"Kumler, "How Shall the Teacher Dress? On What Price 'Smartness'," 550.

"s"Schoolroom Glamour," 36. 
calling, one that depended on a specific, if mainstream, personality. The physical performance of glamour was part of a larger act of performing the self. By normalizing the teachers' image, experts also hoped to normalize teachers in the classroom, to create in the schools a more predictable and, in that sense, more reliable, teaching force.

This is abundantly clear in the advice that teachers received in professional literature but also in their teacher training. Teachers College Professor Clyde R. Miller proclaimed to a lecture room of future teachers that "What a teacher needs is a pretty face, a ready smile, a well-shaped body attractively clothed, and political pull .... And she must be a yeswoman." ${ }^{\text {77 }}$ Miller knew what administrators desired; as director of the Board of Educational Services, he was responsible for placing new teachers in New York City schools. His call to encourage teachers to be yes-women is exemplary of the interwar's struggle with teacher professionalism: experts and administrators wanted teachers to be smart and skilled enough to run their classrooms with ease, but not smart or skilled enough to demand more in return. In other words, by many of the experts and administrators who held the greatest control over them, teachers were encouraged to think of themselves as unique in their devotion and aptitude for managing the classroom and, at the same time, as just another "pretty face."

\section{Developing a Resistance}

The American Teacher asked its readers in 1913, "Would you be a teacher if you didn't have to earn a living?" Before Progressive reform, the answer to this question for most women was no, even if teachers often believed they were doing noble work and, more specifically, saving souls. Studies clearly show that even before official marriage bans existed, women teachers were most often single women who, upon marriage, left the profession almost immediately. Many experts had long hoped that with professionalization, the answer to that question might change. As scholars of early schoolwomen have argued, experts had long depended on teachers believing and employing a salvation narrative to give value to work that often went underrewarded. But explicitly moralistic arguments waned in the twentieth century as a developing professional culture turned to a rhetoric of rationalism. Progressive reform brought science to salvation, redefining teaching as work that preoccupied itself with "build[ing] the bones and muscles of the mind, the sinews of the soul, the very fibres of the spirit." Experts portrayed their new, more professional pedagogues as "Undaunted by difficulties, undismayed by disappointment, unembittered by distrust, the teacher toils at the task so that others may live." 58

\footnotetext{
57"Be Good-Looking, and Let Who Will Be Clever," Newsweek (August 3, 1935): 35.

"s8"On Being a Teacher," HP 16 (October 1934): 18-21, 19.
} 
To emphasize teacher self-sacrifice and to further link that sacrifice to images of physicality was often the wrong tactic for quelling teachers agitated by what they were increasingly coming to see: the standards and responsibilities that accompanied professionalization had advanced far more rapidly than their material rewards. The rhetoric of teacher health aside, the actions of experts and administrators often suggested that they were most interested in how women's bodies would perform in the classroom for the sake of the students, the schools, and the public at large. In popular journals, where they were not edited by administrators, women who had entered the teaching profession during the Progressive Era reflected the doubts that they held about their professional choices and mourned the sacrificing of their own bodies to serve those of others. In Ladies Home fournal, Alma Madden ruminated, "Verging now on middle age, I begin to feel the letting down that is said to come with that period. I have made no bargain with the future; I have saved nothing for my old age. It requires no juggling with figures to see that I am a failure financially .... I wonder if, in the light of spiritual values, I am still a failure. Did I invest my heritage of youth and brain and sinew unwisely? Did I waste my substance? I do not know." 59 Depressing and doubtful, the essay ends here. Unlike many of the narratives in Ladies Home fournal, Madden's story is not revived by a sudden change of heart or an upbeat moral lesson. Rather, her essay showed to its middle-class readers what their working counterparts had come to realize: the Alma Maddens of the world were taking care of their children but the profession was not taking care of them. Were these the conditions Ladies Home fournal readers wanted to send their children into each day? Teachers hoped mothers would say no..$^{60}$

The combination of an expanding consumer culture that depended on women workers and of increased professional standards that required teachers to acquire a college education meant many of the women who were becoming teachers had more occupational choices than their predecessors. They saw that work could and should be more than an economic necessity but a consciously chosen element of their lives. Writing in 1920, Madden could not foresee the Depression or the resulting desperation most teachers would feel to hold onto their jobs at any cost. Nevertheless, the implicit argument in her essay and in others, that women who were able to do better for themselves were going to begin doing so, would be acted upon after World War II. The massive teacher shortages that New York and many other cities faced after the war were one

${ }^{59}$ Alma Madden, "Lo, the Poor School-Teacher," Ladies Home fournal 27 (August 1920): 24-5, 162, 165-166; 166.

${ }^{60}$ Studies of the growing PTA and the cooperation between teachers and mothers in the interwar period show that parents often tried to come teachers' rescue in this period. See William Cutler, Parents and Schools: The 150-Year Struggle for Control in American Education (Chicago: University of Chicago Press, 2000). 
consequence of the frustrations she and other teachers vocalized in the interwar period; the increased number of teacher strikes was another. In the meantime, while more inclined to stay in their profession than their predecessors, teachers were making financial and social sacrifices for their work. They often pointed out that many of the guidelines experts and administrators recommended or demanded for their lives outside of the classroom - to become well-rounded, cultured, if not exactly sophisticated people-were made impossible by the very financial and social restrictions of being a teacher. Women, who faced greater restrictions than men, risked becoming even less like the balanced, attractive people that they were supposed to be both as teachers and as women. "I am not married for several reasons" explained one such teacher "lack of contact with men - a disadvantage of our profession—lack of a social life, lack of money for travel and attractive clothing.... Also, I have been too overworked to maintain the health that makes one attractive." ${ }^{11}$ If administrators wanted teachers to be more desirable people, they argued, they were going to need to make teaching a more desirable profession.

The dissatisfactions teachers felt and expressed in the interwar era pushed administrators to respond. The responses they received were often a mixed lot. Some principals advocated for their staff, reminding superintendents that teachers were being asked to do much more than before: not only teach more students but fill out more paperwork, lead extracurricular clubs and events, and attend more staff meetings. These other duties subtracted from the time teachers had to prepare their lessons, to advance their expertise in the subjects they were teaching, and to be active in the world. Conflicting with a desire to keep teachers happy, however, was administrators' greater concern for keeping the schools running and their proclivity for measuring school success in quantitative rather than qualitative terms. A significant current underlying administrators' interest in healthy teachers was their belief that "a teacher's absence means an irreparable waste of human material." 2 The extra money spent in substitute teachers' salaries only made schools less efficient, as did teachers' desires to be compensated for more work.

In addition, most administrators argued that altruism was still a basic part of the job description. In the Fournal of the National Education Association, Mack Stoker implored, "Even if you don't make more money, even if you don't get promoted, isn't it just possible that the feeling of having done something that was not required of you might sweeten your sleep a little? It isn't my job-or is it? Think it over." ${ }^{33}$ Others crafted arguments more skillfully. In 1920, Assistant Superintendent of the New York City High

\footnotetext{
${ }^{61}$ Donovan, The Schoolma'am 44.

62"A Review of Our Health, Our Honesty, Our Income, Our Art, and Our Safety," Educational Review (April 1927): 175-177, 175.

${ }^{63}$ Mack Stoker, "It Isn't My Job-But Is It?" The Fournal of the National Education Association 29 (January 1940): 20.
} 
Schools John Tildsley wrote ". . teachers who have not the strength to carry two jobs at the same time report that they are gradually exhausting the small savings they have painfully accumulated, that they are year by year steadily lowering their standard of living; that they are forced to give up recreation and opportunities for broadening and enriching their lives; that because of the privations to which they are increasingly subjected, their health is suffering and their spirit is broken...." ${ }^{64}$ Tildsley wrote four years after teachers organized the American Federation of Teachers (AFT) to advocate for higher salaries and increased professional agency; here in this claim he implicates health in both. On one hand, he acknowledged that teachers' bodies suffered from a tiring lifestyle and a lack of a decent standard of living. At the same time, he suggested that teachers physically fail because they do not treat teaching as a profession; teaching was no longer to be one of a number of jobs a woman held but her life's work. Inconsistent messages that gestured towards teachers' salary concerns, yet used professionalism as a rallying cry to subordinate those concerns, remained typical of the era.

If organized labor wanted to present itself as a collective body, administrators wanted to define the term as a newly professional force, one that could be contaminated by a single, infected organism. Administrators like Tildsley were aware that classrooms were overcrowded and that teachers' administrative and extracurricular duties had only increased. In the end, however, they offered little in the way of solutions other than imposing a differentiated curriculum, and evaluating teacher performance became a means for diagnosing teachers' problems and turning them back upon themselves. "Discouragement is infectious" was a theme echoed by New York City administrators. Poor teachers served as "a positive injury" to the faculty as a whole, Tildsley reminded his teachers, for "as in every calling with union rules... all alike must tend to be paid what the marginal worker, not the best worker, is worth." ${ }^{\prime 5}$ By critiquing "marginal workers" and "union rules" at once, Tildsley suggested that both posited equal harm to effective teachers who were being undercompensated. In defining relationships between work and salary as causal in nature, administrators argued that there existed a science to professionalism and to professional rewards. ${ }^{66}$

${ }^{64}$ John L. Tildsley, "The Crisis in Education," HP 2 (April 1920): 31-35, 33.

${ }^{65} H P 9$ (September 1927): 134, 142.

${ }^{66}$ Though records of school budgets certainly exist, it is difficult to know how many teachers received merit raises and what the classrooms of such teachers might have looked like. One thing we definitely do know is that teachers' salaries were consistently jeopardized throughout the Depression. See Marjorie Murphy, Blackboard Unions: The AFT and the NEA, 1900-1980. (Ithaca: Cornell University Press, 1990). Celia Zitron shows that New York City teachers returned over two million dollars to the school board in 1932 in the form of $5 \%$ "voluntary" salary contributions for needy children. Zitron also records salary cuts throughout the 1930s and the debate over the Board of Education's use of substitute teachers (like Freistater) to semipermanently occupy teaching positions for less pay than certified teachers. Zitron, The New York City Teachers Union, 1916-1964 (New York: Humanities Press, 1968), 127 and following. 
Union leaders such as Henry Linville understood the way in which administrators associated teachers' health with a well-running system and healthy school body. In The American Teacher, the national publication of the AFT, Linville responded to claims like Tildsley's and explained "When educational systems are forced to pay for overtime work, their managers may realize the necessity of changing conditions in such a way as to make administration less expensive. Among these changes might well be changes in conditions which make teachers sick." ${ }^{67}$ If schools made teachers sick, labor activists rejected the notion that this was due to some deficiency in the teacher. Throughout the interwar period, the AFT petitioned for increased salaries and smaller and more manageable classrooms as a means to reduce stress on teachers. In so doing, it reacted against experts and administrators who portrayed teacher agency as unprofessional and ailing teachers as lax or weak. At stake more largely was a desire for teachers to profit from professionalism without sacrificing their ability to self-advocate and self-regulate.

Within this culture of growing awareness of their professional advocacy, however, male and female teachers faced different abilities and limitations in articulating resistance, differences that were rooted in the distinct ways in which the profession worked to discipline women. These abilities and limitations were often marked by how teachers drew on the lingua franca of the day, the rhetoric of mental and bodily health that came to be the language of professionalism. This language reflected an increasing acknowledgment of the self as a mutable, influential, and measurable entity and of the physical representation of selfhood. If administrators and experts wanted to portray a faculty skirting the edge of self-control, some teachers were willing at times to exploit that image for their own interests. For example, Joseph Mersand of Boys High School wrote, "No teacher can preserve his equanimity in the face of salary cuts, threats to his mandatory salary increases and his pension rights, interference with his freedom of expression, suspicions to his loyalty and patriotism. How can one preserve a sound mind in the face of all these petty attacks which may not amount to much individually, but which collectively destroy one's peace of mind?" 68 Mersand's claim to psychological preservation directly countered experts' allegations that teaching was attracting the wrong types. More fervently than R.I.P., he suggested that teachers were not just passive victims but could blame potential insanity or disillusionment, at least, on a culture of surveillance that had developed around the profession. Like Linville, Mersand manipulated experts' and administrators' anxieties over teachers' mental health to demand an increased salary and an increased freedom of speech and political belief. Both writers, then, used the rhetorical

67"Time and a Half," The American Teacher 8 (April 1919), 76.

${ }^{68} \mathrm{~J}$ oseph Mersand, "The Teacher and the Pupil's Mental Health," HP 20 January 1938): 19-24, 21. 
bodies and minds in their texts in the same way that unions used collective bodies in reality: to bargain for privileges and liberties that can only be negotiated in a public, political arena. In this sense, Mersand and Linville exhibited a form of defiance that presumed bodies can serve as powerful tools of resistance. To believe this, both men also had to believe that there was a way for bodies to perform outside the classroom that could alter what occurred within it. ${ }^{69}$

Ironically, that same belief served as the foundation of the administrative standards women teachers faced in interwar America, and this shared assumption prevented male labor leaders from seeing and advocating against the problems that female teachers faced specifically. The writing this essay centers on captures the pressures that women teachers experienced to discipline their bodies and minds in and outside the classroom and the difficulties many teachers exhibited in responding to them. In contrast to Mersand's attack on loyalty oaths, the pitiful regret of Alma Madden and the satirical barbs of R.I.P. present their minds and bodies as sites of physical decay and isolation rather than as entities interactive with education politics. Neither R.I.P. nor Madden can see beyond the physical landscape of their own bodies, even if they both want to protest the professional inequities they experience. The feminized teachers' bodies that readers encounter in the literature of the interwar period remain confined to the classroom; and, as Madden and R.I.P. remind readers, the classroom is both a restricted and restrictive space. Consciously or not, interwar teachers comment on the limitations of the classroom, socially (in its preventing good women from meeting desirable men), intellectually (in the way it encourages women to obsess over details rather than expand their knowledge), and politically (in its subordinated status to the political currency of the administrative world). Ultimately, however, their difficulty in moving beyond comment and into an explicit discourse of resistance is significant of a larger, troubled relationship in the interwar period between bodies and agency in school politics. If the realm of labor activism was clearly a public space, the classroom was configured as a private one, even as administrators entered it at will. This happened not just through the continual positioning of women as caretakers and, therefore, as domestic workers, but also through the construction of the classroom as localized and distinct from the bureaucracies that attempted to define it. At the same time that experts worked to shape women's political lives, the disciplining of the professional teacher reflected the degree to which they thought of the classroom as self-contained and

\footnotetext{
${ }^{69}$ Marjorie Murphy shows that the first ten years of the AFT (the time in which Linville wrote), in fact, privileged male leadership, something that may have bearing here. This would change in 1926 with the "revolt" of women in the AFT, but, as Murphy argues, teachers unions in New York, especially, were not nearly as powerful or popular before World War II as they would be after. Murphy, Blackboard Unions, 84-5 and 117 and following.
} 
self-referential: the problems that inevitably occurred within it were continually defined as problems caused by the bodies that occupied it, both student and teacher, rather than the governing bodies that surrounded it.

This configuration and isolation of the classroom was exhibited in and enabled by the focus on typing, on self-fashioning, and on healtheach of which subordinated individual expression to cultural expectations and beliefs, all the while claiming an interest in specific, particular bodies. Altogether, these concerns gave administrators a framework for interpreting classrooms that were far more complicated than singular education theories could account for and that were influenced daily by the unpredictable factors produced by social life. But disciplining the teacher had important political implications as well. As long as experts focused on "feminine" values and skills, compensation was something of a nonissue, for neither sympathy nor nurturance had any value in the marketplace. The ways in which experts defined "good women" in the first half of the twentieth century changed over time, though they remained preoccupied with the concept. Before Progressive reform, much of the rhetoric of education literature worked to erase any sense of exceptionality in what women accomplished in the classroom because such work was considered natural to them. After Progressive reform, however, and with the changing cultural beliefs about selfhood, came a sense that teaching was not just sympathetic work but deliberate, scientific, and learned and, therefore, more potentially powerful. The Freistater case exemplifies some of the complicated and contradictory ramifications of this cultural shift. Administrators could not take away Freistater's expertise; her own chairman testified that she was a success in the classroom. Instead, they could only take her body out of the schools.

Rose Freistater's story was significant of a trend that, by the interwar period, was clearer than it had been in the decades that preceded it: in the process of professionalization, teachers had exchanged one kind of agency for another. With the increased status and sense of professional discipline that teachers earned in the Progressive Era came a greater attention from those who considered themselves education experts. In 1938, Francis Donovan quoted a teacher who explained "Because I am a teacher I dare not be frivolous and outspoken in my conversation." ${ }^{\text {" }}$ It is easy to imagine a woman speaking these same words a century earlier in response to the community pressures common school teachers faced. Even within a completely new system, one that claimed to redefine the new "professional teacher" from the women who preceded them, many still felt deferent and restricted. Community control had been replaced in large part by administrative control; one of the most stabilizing factors within the flux of political, structural, and sociological changes that public schools experienced before and after

${ }^{70}$ Donovan, The Schoolma'am, 44. 
World War I was the limited autonomy most teachers held. Whether rural spinster or urban professional, women teachers both before and after Progressive reform were expected to give more to their job than they received, to abide by cultural norms, and to conform their lives, their bodies, and their ideas to the public will. 